\title{
Down-regulation of MMP-2 expression due to inhibition of receptor tyrosine kinases by imatinib and carboplatin in HNSCC
}

\author{
JOHANNES D. SCHULTZ ${ }^{1}$, SARAH ROTUNNO ${ }^{1}$, PHILIPP ERBEN ${ }^{2}$, J. ULRICH SOMMER ${ }^{1}$, CLEMENS ANDERS $^{1}$, \\ JENS STERN-STRAETER ${ }^{1}$, RALF-DIETER HOFHEINZ ${ }^{2}$, KARL HÖRMANN ${ }^{1}$ and ALEXANDER SAUTER ${ }^{1}$
}

Departments of ${ }^{1}$ Otorhinolaryngology, Head and Neck Surgery, and ${ }^{2}$ Haematology and Oncology, University Hospital Mannheim, Mannheim, Germany

Received August 17,2010; Accepted September 30, 2010

DOI: $10.3892 /$ or.2011.1153

\begin{abstract}
Squamous cell carcinoma of the head and neck (HNSCC) is the most common neoplasm arising in the upper aerodigestive tract. Unfortunately, the survival for this type of cancer has not improved significantly in the past 25 years. To enhance the survival rate multimodal therapy regimens have been set up. In these regimens chemotherapy plays a pivotal role in the majority of advanced cases. Transmembrane proteintyrosine kinases (PTK) are fundamental elements of the signal transduction. In consequence, they might be promising targets for cancer therapy. Imatinib (STI 571) was originally designed to inhibit the BCR-ABL tyrosine kinase in chronic myeloid leukemia. But imatinib also has an inhibitory impact on the PTK receptor c-kit and on its PTK activity. Furthermore, growth and invasion of HNSCC are strongly influenced by the extracellular matrix (ECM). The ECM is altered by matrix metalloproteinases (MMP). In this study, we incubated different HNSCC cell lines with rising concentrations of imatinib and/or carboplatin. After an incubation time of up to 10 days, we evaluated c-kit, MMP-2 and MMP-14 by ELISA techniques and immunohistochemical methods. Especially the combination of $7.5 \mu \mathrm{mol}$ carboplatin with $30 \mu \mathrm{mol}$ imatinib resulted in a significant decrease in MMP-2 expression in all observed cell lines $(\mathrm{p}<0.05)$. We did not demonstrate a significant alteration in c-kit expression by imatinib and carboplatin. We observed an increase in apoptosis in HNSCC cells by the combination of the two observed chemotherapeutic drugs. In all cell lines tested, expression of c-kit and MMP could be demonstrated. Our results indicate that MMP-2 expression was suppressed in the presence of imatinib. Thus, imatinib may exert in part its inhibitory effect on malignant cell growth via the blockage of the signal transduction
\end{abstract}

Correspondence to: Dr Alexander Sauter, Universitaets-HNOKlinik, Theodor-Kutzer-Ufer 1-3, D-68135 Mannheim, Germany E-mail: alexander.sauter@gmail.com

Key words: protein tyrosine kinase, head and neck squamous cell carcinoma, cell culture, imatinib, carboplatin, matrix metalloproteinase of PTK receptors. Further studies are warranted, especially one keeping in mind the moderate toxicity of imatinib.

\section{Introduction}

Head and neck squamous cell carcinoma (HNSCC). HNSCC is an aggressive epithelial malignancy. It is the most common neoplasm arising in the upper aerodigestive tract. According to actual data, HNSCC was ranked as the sixth of the most common cancers in the world (1). Unfortunately, the survival for this type of cancer has not improved significantly in the past 25 years (2). The overall 5-year relative survival rate from HNSCC is less than $50 \%$ (3). The management of the malignancy requires multimodal therapy including surgery, chemoradiation and often the combination of these strategies (2). Chemotherapy is employed in the majority of the advanced cases but the response rates are poor (3). Thus, new treatment modalities are developed to improve long-term survival in HNSCC disease. In the past years, many biological markers have been described in HNSCC. For example, various studies have suggested potential prognostic values for p53 mutations, enhanced expression of epidermal growth factor (EGFR), transforming growth factor (TGF) $\alpha$, or cyclin D1 (4-6). More recently, novel CD44v6 targeting humanized antibodies were coupled to toxic substances in order to improve response rates in $\operatorname{HNSCC}(7)$.

Protein-tyrosine kinases (PTK). An essential element of signal transduction pathways are PTKs. The intracellular signal transduction is of essential interest in cell growth, metastasis and apoptosis. Numerous factors regulate the activities of these PTKs. However, genetic alterations of PTKs often cause malignant transformations (8). Especially transmembrane PTK receptors are of interest. These receptors are responsible for the transduction of signals from outside and inside the cell. PTKs are important targets for chemical agents that inhibit their activities. In HNSCC only the EGFR-PTK inhibitor gefitinib (Iressa ${ }^{\circledR}$ ) has been studied extensively (9).

Imatinib. The PTK inhibitor imatinib (Glivec ${ }^{\circledR}$ or Gleevec ${ }^{\circledR}$, also known as STI 571, Novartis, Basel, Switzerland) belongs to the 2-phenylaminopyrimidine class, which was developed 
Table I. Characteristics of the cell lines.

\begin{tabular}{lcccc}
\hline Cell line & Gender & Primary tumor location & Specimen site & Type of lesion \\
\hline UM-SCC 11B & Male & Supraglottic larynx & Larynx & Metastatic tumor \\
UM-SCC 14C & Male & Floor of the mouth & Oral cavity & Local recurrence \\
UM-SCC 22B & Male & Sinus piriformis & Hypopharynx & Metastatic tumor \\
\hline
\end{tabular}

for its selectivity against BCR-ABL in patients with chronic myeloid leukemia (CML) (10), but, it is also an inhibitor of platelet-derived growth factor receptor (PDGFR) PTK $(11,12)$. Recently, the crucial role of PDGFR in HNSCC growth has been described (13). In 2000, a close homology between the PTK domains of PDGFR and the PTK receptor c-kit has been published (14). The PTK receptor c-kit is a $145 \mathrm{kDa}$ transmembrane protein and the product of the c-kit gene. Imatinib exclusively inhibits c-kit PTK activity and thus activation of various other proteins, which are necessary in proliferation and long-term survival of leukemic cell groups (14). The inhibitory effects of imatinib are brought about by binding with non-reserved amino acid residues in the ATP binding site of mutant PTKs (11). In consequence the auto-phosphorylation is being blocked and an alteration of the PTK is taking place (12).

c-kit. In several solid tumors, such as GIST and breast cancer, c-kit has been described as overexpressed $(15,16)$. Recently, the first report about the expression of c-kit in HNSCC has been published. The authors described a significantly higher expression of c-kit in HNSCC compared to benign samples. Surprisingly the expression of c-kit was significantly elevated in carcinomas of the pharynx compared to carcinomas of the larynx (17), but also over $90 \%$ of the adenoid cystic carcinomas of the head and neck are c-kit positive. The treatment of adenoid cystic carcinoma primary cultures with imatinib showed a down-regulation of c-kit expression and growth-inhibition (18).

MMP-2. Matrix metalloproteinases (MMP) represent a family of zinc- or calcium-dependent endopeptidases. MMPs degrade as gelatinases the extracellular matrix (ECM). This degradation of the ECM plays a key role in tumor angiogenesis, tumor progression and facilitates metastasis. Expression of MMP-2 is associated with tumor invasion and metastasis in HNSCC (19). Okada et al reported that the majority of MMPs are generated in the stromal compartment by fibroblast tissue surrounding the tumor (20).

The purpose of this study was to evaluate the effects of imatinib (STI 571) in HNSCC cell culture. The expression of c-kit, MMP-2 and apoptosis was analysed not only after incubation with imatinib but also after combination of imatinib with carboplatin. To our knowledge, this is the first report of a chemotherapeutic study treating HNSCC with imatinib and carboplatin.

\section{Materials and methods}

Cell culture. The three different UM-SCC cell lines 11B, $14 \mathrm{C}$ and 22B were obtained from Dr T.E. Carey (University of Michigan, MI, USA). These cell lines originate from human HNSCC of the oro-, hypopharynx and larynx. Cell cultures were carried out at $37^{\circ} \mathrm{C}$ in a $5 \% \mathrm{CO}_{2}$ fully humidified atmosphere using Dulbecco's modified minimum essential medium (DMEM) (Fisher Scientific Co., Pittsburgh, PA, USA) supplemented with $10 \%$ fetal calf serum (FCS) and antibiotics (Life Technologies Inc., Gainthersburg, MD, USA). Imatinib was gratefully provided by the manufacturer (Novartis). Imatinib and carboplatin (Medac, Wedel, Germany) was stored at $4^{\circ} \mathrm{C}$ and dissolved in sterile water at the time of use. The HNSCC cell lines were incubated with different concentrations and combinations of imatinib and/or carboplatin from $48 \mathrm{~h}$ to 10 days. After the defined incubation time the supernatants were collected in sterile tubes and stored at $-20^{\circ} \mathrm{C}$ until further analysis (Table I).

C-Kit/MMP-ELISA principle. c-kit and MMP-2 concentrations were determined by ELISA technique (c-kit: sCFsR, DSCR00; MMP-2: DMP2F0, R\&D Systems, Wiesbaden, Germany). The system used a solid-phase monoclonal antibody and further an enzyme-linked polyclonal antibody against c-kit or MMP-2. The specificity of anti-human antibodies used in the ELISA kit were examined by sodium dodecylsulphate polyacrylamide gel electrophoresis (SDSPAGE) followed by further Western blotting. Following the manufacturer's instructions, each assay measured $100 \mu 1$ of supernatant. All calibrations and analyses were carried out in duplicate. The calibrations on each microtiter plate included c-kit standards provided in the kit. Optical density was determined using a micro-plate reader at a wavelength of $450 \mathrm{~nm}$. Wavelength correction was set to $540 \mathrm{~nm}$. Concentrations of c-kit and MMP-2 were reported as ng/ml. After $48,72 \mathrm{~h}, 5$ and 10 days of incubation with 3 or $7.5 \mu \mathrm{mol}$ carboplatin, 18 or $30 \mu \mathrm{mol}$ imatinib, $3 \mu \mathrm{mol}$ carboplatin and $18 \mu \mathrm{mol}$ imatinib, $7.5 \mu \mathrm{mol}$ carboplatin and $30 \mu \mathrm{mol}$ imatinib, the expression of c-kit or MMP-2 in the supernatants of the incubated cultures and untreated cultures was determined.

Characterisation of the cell lines (immunohistochemistry). Immunohistochemical studies were performed using a monoclonal mouse anti-human antibody directed against c-kit (NB 100-1766, Novus Biologicals, Littleton, USA) and MMP-14 (ab73879, Abcam, Cambridge, UK). Immunostaining was performed using the streptavidin horseradish method. The cells were cultured on Nunc eight well chambers overnight before immunohistochemistry. When confluent, cells underwent a fixation with acetone and alcohol (2:1), were washed with PBS and dried overnight at $37^{\circ} \mathrm{C}$. Slides were rinsed in PBS. Cells were incubated with the primary antibody solution for $30 \mathrm{~min}$ at room temperature, using a 
work dilution of antibody to cells of 1:300. Slides were rinsed three times in buffer (Buffer Kit, Dako, Hamburg, Germany). Furthermore, the cells were incubated in normal sheep serum. Immunoreaction was demonstrated with the monoclonal mouse anti-human antibody c-kit (NB 100-1766, Novus Biologicals) and MMP-14 (ab73879, Abcam). The incubation was followed by a specific biotinylated secondary antibody and a strepatvidin-biotin horseradish peroxidase complex (Amersham, Freiburg, Germany). After that peroxidase reaction was performed using aminoethylcarbazol as chromogen. After blocking of endogenous peroxidase, cells were washed various times. Finally sections received a counterstaining with Harris' hematoxylin for $30 \mathrm{sec}$. This procedure was followed by coverslipping. Negative controls used all reagents except the primary antibody. The results of the immunohistochemically observed rates of expression were determined semi-quantitatively. The stain intensity was described as follows: strong reactivity, $>80 \%$ of the cells were positive; moderate reactivity, $50-80 \%$ of the cells stained positive; weak reactivity, $<50 \%$ of the cells were positive; and no positive cells.

Statistical analysis. For statistical analysis was performed in cooperation with Mrs. Dr C. Weiss, Institute of Biomathematics, Faculty of Medicine, Mannheim. The differences in c-kit and MMP expression between incubated cultures and control cultures were analyzed using the Dunnet's test being part of GLM procedure. All data were subjected to the Means procedure. A p-value $\leq 0.05$ was considered statistically significant.

\section{Results}

Effect of carboplatin and imatinib on HNSCC cell lines. To analyze the effects of imatinib and carboplatin on UM-SCC cell lines, we added rising concentrations of the two chemotherapeutical agents (imatinib 18 and $30 \mu \mathrm{mol}$; carboplatin 3 and $7.5 \mu \mathrm{mol}$ ). In order to determine MMP-2 as well as c-kit expression in the supernatant of the cell lines, ELISA was carried out after 2, 3, 5 and 10 days after the start of incubation.

In UM-SCC 11B MMP-2 levels in all treated and control cultures were measured as mean $0.307 \mathrm{ng} / \mathrm{ml}(\mathrm{SD} \pm 0.072)$ after $48 \mathrm{~h}, 0.371 \mathrm{ng} / \mathrm{ml}(\mathrm{SD} \pm 0.131)$ after $72 \mathrm{~h}, 0.493 \mathrm{ng} / \mathrm{ml}$ $(\mathrm{SD} \pm 0.312)$ after 5 days and $0.519 \mathrm{ng} / \mathrm{ml}(\mathrm{SD} \pm 0.384)$ after 10 days. But the analysis of the various treatment options revealed a difference in MMP expression. After incubation with $3 \mu \mathrm{mol}$ carboplatin and $18 \mu \mathrm{mol}$ imatinib a mean MMP expression of $0.3 \mathrm{ng} / \mathrm{ml}$ was measured, without regarding the duration of incubation. The incubation with 18 or $30 \mu \mathrm{mol}$ imatinib with or without $7.5 \mu \mathrm{mol}$ carboplatin showed a mean expression of $0.2 \mathrm{ng} / \mathrm{ml}$ ( $\mathrm{SD} \pm 0.1$ with carboplatin, \pm 0.0 without carboplatin). MMP-2 expression after incubation with $3 \mu \mathrm{mol}$ carboplatin and $18 \mu \mathrm{mol}$ imatinib showed a decrease of $12.25 \%$. The incubation with $7.5 \mu \mathrm{mol}$ carboplatin and $30 \mu \mathrm{mol}$ imatinib resulted in a stable situation, and $30 \mu$ mol imatinib showed a decrease of $16.82 \%$ of MMP-2. The comparison of the MMP expression after the treatment with $3 \mu \mathrm{mol}$ carboplatin and $18 \mu \mathrm{mol}$ imatinib, $7.5 \mu \mathrm{mol}$ carboplatin and $30 \mu \mathrm{mol}$ imatinib, and $30 \mu \mathrm{mol}$ imatinib

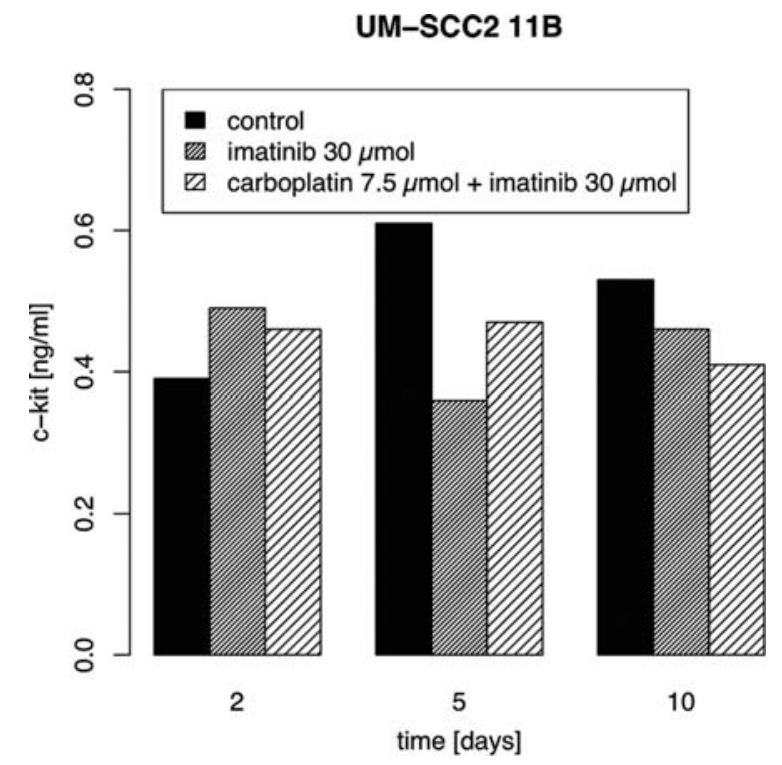

Figure 1. c-kit expression in UM-SCC 22B after incubation with imatinib $30 \mu \mathrm{mol}$ and the combination of $30 \mu \mathrm{mol}$ imatinib and additional $7.5 \mu \mathrm{mol}$ carboplatin.

revealed a significant decrease to the control groups $(\mathrm{p}<0.05)$. In UMM-SCC $11 \mathrm{~B}$ cell cultures c-kit expression was also determined using ELISA techniques. The mean expression of c-kit was determined $0.4 \mathrm{ng} / \mathrm{ml}(\mathrm{SD} \pm 0.0)$ after incubation with $30 \mu \mathrm{mol}$ imatinib, but for example $1.4 \mathrm{ng} / \mathrm{ml}(\mathrm{SD} \pm 1.3)$ after incubation with $7.5 \mu \mathrm{mol}$ carboplatin. We could not observe a statistically significant difference in c-kit expression compared to the controls in the 11B cell lines (Fig. 1). The determination of the total protein content showed a decrease after incubation, for example a decrease of $66 \%$ after 10 days of incubation with $3 \mu \mathrm{mol}$ carboplatin and $18 \mu \mathrm{mol}$ imatinib in UM-SCC 11B. The mean concentrations of total protein was from $264.8 \mu \mathrm{g} / \mathrm{ml}(\mathrm{SD} \pm 277.0)$ after treatment with $30 \mu \mathrm{mol}$ imatinib to $1269.0 \mu \mathrm{g} / \mathrm{ml}(\mathrm{SD} \pm 136.9)$ in the control groups. Furthermore, the treatment with $18 \mu \mathrm{mol}$ and $30 \mu \mathrm{mol}$ imatinib alone, and $3 / 7.5 \mu \mathrm{mol}$ carboplatin and $18 / 30 \mu \mathrm{mol}$ imatinib resulted in a significant decrease in total protein $(\mathrm{p}<0.05)$ in UMM-SCC $11 \mathrm{~B}$.

In UMM-SCC 22B the mean MMP-2 expression ranged from $0.8 \mathrm{ng} / \mathrm{ml}(\mathrm{SD} \pm 0.6)$ during treatment with $30 \mu \mathrm{mol}$ imatinib up to $2.9 \mathrm{ng} / \mathrm{ml}(\mathrm{SD} \pm 1.1)$ in treatment with $3 \mu \mathrm{mol}$ carboplatin. We observed a statistically significant difference concerning MMP-2 expression after treatment with $30 \mu \mathrm{mol}$ imatinib and $7.5 \mu \mathrm{mol}$ carboplatin with $30 \mu \mathrm{mol}$ imatinib compared to the control groups $(\mathrm{p}<0.05)$ (Fig. 2). Similarly to UM-SCC $11 \mathrm{~B}$, we failed to determine a statistically significant alteration in c-kit expression. The results concerning the total protein content corresponded to those from $11 \mathrm{~B}$.

In UM-SCC $14 \mathrm{C}$ we observed a ten times higher expression of MMP-2 compared to 22B and 11B. Repeated assays revealed similar results and ratios. The mean MMP-2 expression after treatment with $7.5 \mu \mathrm{mol}$ carboplatin with $30 \mu \mathrm{mol}$ imatinib amounted to $11.0 \mathrm{ng} / \mathrm{ml}(\mathrm{SD} \pm 8.6)$, being the lowest MMP-2 expression compared to other regimens. A mean MMP-2 expression of $46.8 \mathrm{ng} / \mathrm{ml}(\mathrm{SD} \pm 11.5)$ 


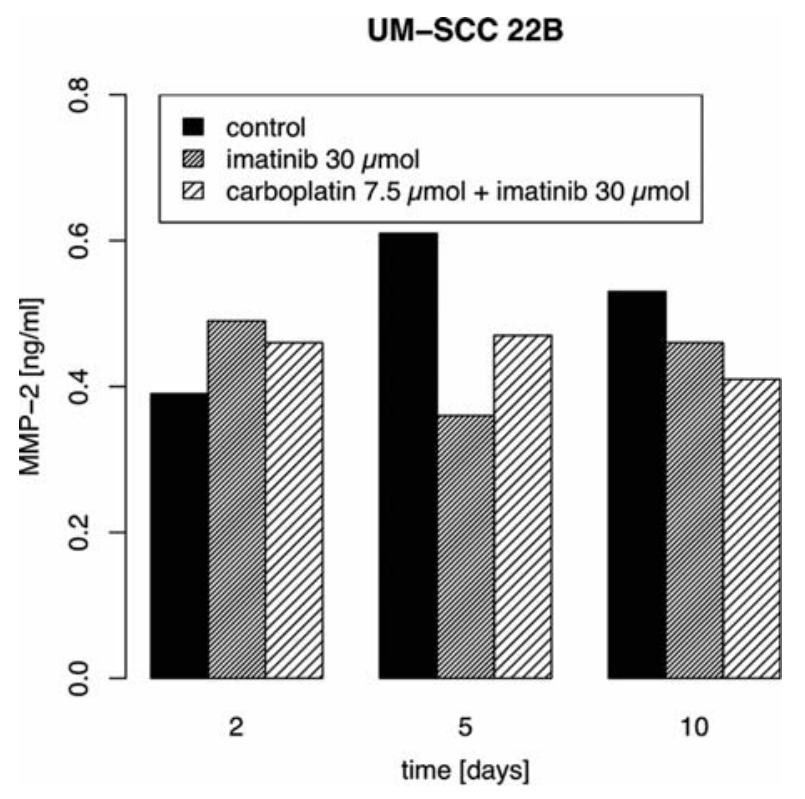

Figure 2. MMP-2 expression in UM-SCC 22B after incubation with imatinib $30 \mu \mathrm{mol}$ and the combination of $30 \mu \mathrm{mol}$ imatinib and additional $7.5 \mu \mathrm{mol}$ carboplatin.

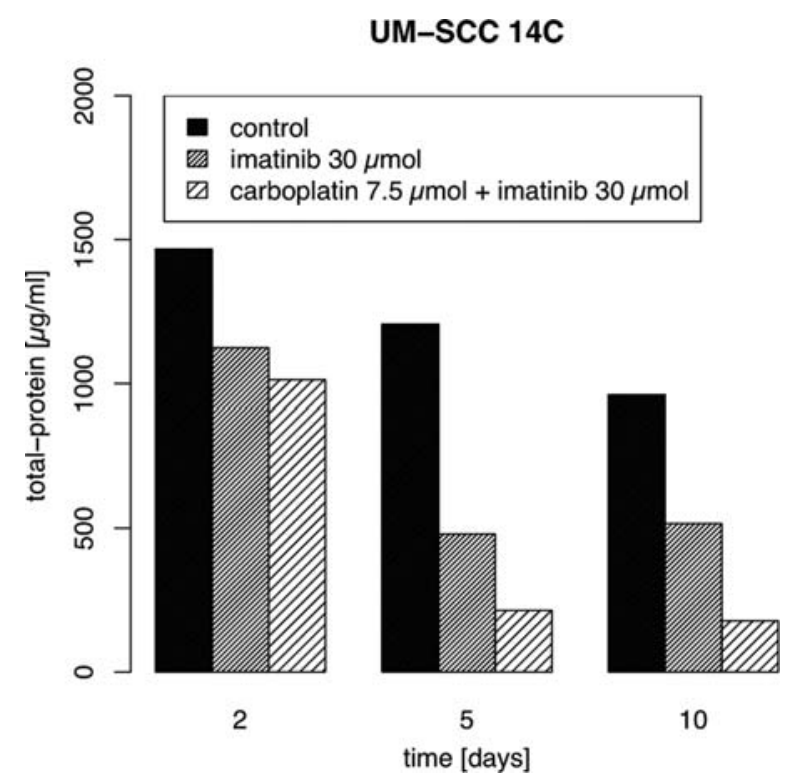

Figure 3. Total protein content in UM-SCC $14 \mathrm{C}$ after incubation with imatinib $30 \mu \mathrm{mol}$ and the combination of $30 \mu \mathrm{mol}$ imatinib and additional $7.5 \mu \mathrm{mol}$ carboplatin.

was determined after sole carboplatin treatment. Although the UM-SCC 14C cultures showed differences in MMP-2 expression in absolute numbers in comparison to $22 \mathrm{~B}$ and $11 \mathrm{~B}$, the relations to the control groups remained identical. The treatment with $30 \mu \mathrm{mol}$ imatinib and $7.5 \mu \mathrm{mol}$ carboplatin with $30 \mu \mathrm{mol}$ imatinib resulted in a significant decrease in MMP-2 expression compared to the control groups $(\mathrm{p}<0.05)$. The analysis of c-kit expression showed no significant alteration, whereas the two above-mentioned regimens induced a significant decrease of total protein content as a sign for enhanced apoptosis (Figs. 3 and 4).

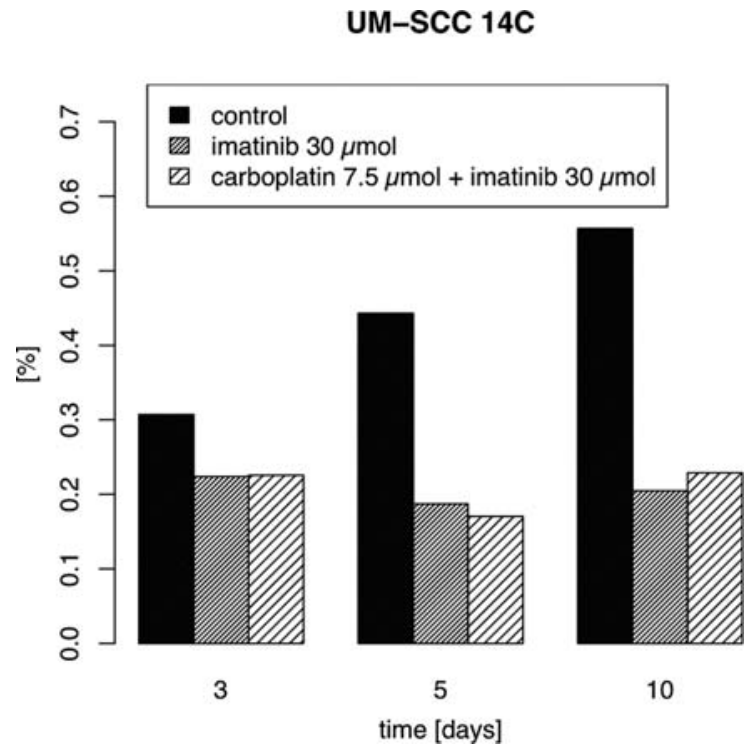

Figure 4. Percentage of MMP-2 in regard of the total protein in UM-SCC $14 \mathrm{C}$ after incubation with imatinib $30 \mu \mathrm{mol}$ and the combination of $30 \mu \mathrm{mol}$ imatinib and additional $7.5 \mu \mathrm{mol}$ carboplatin.

Table II. Immunostaining against MMP-14 in UM-SCC cell lines.

\begin{tabular}{|c|c|c|c|c|}
\hline $\begin{array}{l}\text { Immunostaining } \\
\text { index }\end{array}$ & Day 2 & Day 3 & Day 5 & Day 10 \\
\hline Control & $++(3 / 3)$ & $\begin{array}{l}++(2 / 3) \\
+++(1 / 3)\end{array}$ & $\begin{array}{l}++(2 / 3) \\
+++(1 / 3)\end{array}$ & $+++(3 / 3)$ \\
\hline $\begin{array}{l}\text { Carboplatin } \\
3 \mu \mathrm{mol}\end{array}$ & $\begin{array}{l}+(1 / 3) \\
++(2 / 3)\end{array}$ & $\begin{array}{c}+(1 / 3) \\
++(1 / 3) \\
+++(1 / 3)\end{array}$ & $\begin{array}{l}++(2 / 3) \\
+++(1 / 3)\end{array}$ & $\begin{array}{l}++(1 / 3) \\
+++(2 / 3)\end{array}$ \\
\hline $\begin{array}{l}\text { Carboplatin } \\
7.5 \mu \mathrm{mol}\end{array}$ & $\begin{array}{l}+(2 / 3) \\
++(1 / 3)\end{array}$ & $\begin{array}{l}+(2 / 3) \\
++(1 / 3)\end{array}$ & $\begin{array}{l}+(2 / 3) \\
++(1 / 3)\end{array}$ & $\begin{array}{c}+(2 / 3) \\
+++(1 / 3)\end{array}$ \\
\hline $\begin{array}{l}\text { Imatinib } \\
18 \mu \mathrm{mol}\end{array}$ & $\begin{array}{l}+(2 / 3) \\
++(1 / 3)\end{array}$ & $\begin{array}{l}+(2 / 3) \\
++(1 / 3)\end{array}$ & $\begin{array}{c}+(1 / 3) \\
++(1 / 3) \\
+++(1 / 3)\end{array}$ & $\begin{array}{c}+(1 / 3) \\
+++(2 / 3)\end{array}$ \\
\hline $\begin{array}{l}\text { Imatinib } \\
30 \mu \mathrm{mol}\end{array}$ & $\begin{array}{l}0(1 / 3) \\
+(2 / 3)\end{array}$ & $\begin{array}{l}0(1 / 3) \\
+(2 / 3)\end{array}$ & $\begin{array}{l}0(1 / 3) \\
+(2 / 3)\end{array}$ & $\begin{array}{r}0(1 / 3) \\
+(1 / 3) \\
+++(1 / 3)\end{array}$ \\
\hline $\begin{array}{l}\text { Carboplatin } \\
3 \mu \mathrm{mol}+ \\
\text { imatinib } \\
18 \mu \mathrm{mol}\end{array}$ & $\begin{array}{l}+(2 / 3) \\
++(1 / 3)\end{array}$ & $\begin{array}{l}+(2 / 3) \\
++(1 / 3)\end{array}$ & $\begin{array}{c}+(1 / 3) \\
+++(2 / 3)\end{array}$ & $\begin{array}{c}+(2 / 3) \\
+++(1 / 3)\end{array}$ \\
\hline $\begin{array}{l}\text { Carboplatin } \\
7.5 \mu \mathrm{mol}+ \\
\text { imatinib } \\
30 \mu \mathrm{mol}\end{array}$ & $+(3 / 3)$ & $\begin{array}{l}0(2 / 3) \\
+(1 / 3)\end{array}$ & $0(3 / 3)$ & $0(3 / 3)$ \\
\hline
\end{tabular}

Grading of immunostaining: 0, no positive cells; 1 , weak immunostaining; 2, moderate immunostaining; 3 , strong immunostaining. (x/3), number of positive cell lines out of the UMSCC lines $14 \mathrm{C}$, $11 \mathrm{~B}$ and $22 \mathrm{~B}$. 
Table III. Immunostaining against c-kit (CD 117) in UM-SCC cell lines.

\begin{tabular}{lcccc}
\hline $\begin{array}{l}\text { Immunostaining } \\
\text { index }\end{array}$ & Day 2 & Day 3 & Day 5 & Day 10 \\
\hline Control & $+(3 / 3)$ & $0(2 / 3)$ & $0(2 / 3)$ & $0(2 / 3)$ \\
& & $+(1 / 3)$ & $+(1 / 3)$ & $+(1 / 3)$ \\
Carboplatin & $0(2 / 3)$ & $0(1 / 3)$ & $0(2 / 3)$ & $0(3 / 3)$ \\
$3 \mu$ mol & $+(1 / 3)$ & $++(2 / 3)$ & $+(1 / 3)$ & \\
Carboplatin & $0(2 / 3)$ & $0(2 / 3)$ & $0(2 / 3)$ & $0(2 / 3)$ \\
$7.5 \mu$ mol & $+(1 / 3)$ & $+(1 / 3)$ & $+(1 / 3)$ & $+(1 / 3)$ \\
Imatinib & $0(2 / 3)$ & $0(2 / 3)$ & $0(2 / 3)$ & $0(2 / 3)$ \\
$18 \mu$ mol & $+(1 / 3)$ & $+(1 / 3)$ & $+(1 / 3)$ & $+(1 / 3)$ \\
Imatinib & $0(3 / 3)$ & $0(2 / 3)$ & $0(1 / 3)$ & $0(2 / 3)$ \\
$30 \mu$ mol & & $+(1 / 3)$ & $+(2 / 3)$ & $+(1 / 3)$ \\
Carboplatin & $0(3 / 3)$ & $0(2 / 3)$ & $0(2 / 3)$ & $0(2 / 3)$ \\
$3 \mu$ mol + imatinib & & $+(1 / 3)$ & $+(1 / 3)$ & $+(1 / 3)$ \\
$18 \mu$ mol & & & & \\
Carboplatin & $1(3 / 3)$ & $0(3 / 3)$ & $0(3 / 3)$ & $0(3 / 3)$ \\
$7.5 \mu$ mol +imatinib & & & & \\
$30 \mu$ mol & & & & \\
\hline
\end{tabular}

Grading of immunostaining: 0 , no positive cells; 1 , weak immunostaining; 2, moderate immunostaining; 3 , strong immunostaining. $(\mathrm{x} / 3)$, number of positive cell lines out of the UMSCC lines $14 \mathrm{C}$, $11 \mathrm{~B}$ and $22 \mathrm{~B}$.

Immunohistochemistry. The immunohistochemical studies against MMP-14 showed decreased reactivity with rising concentrations of imatinib and especially the combination of imatinib and carboplatin (Table II). The controls showed less reactivity. Furthermore, therapy with carboplatin or therapy with imatinib and carboplatin alone could not induce a broad decrease in reactivity in c-kit (Table III and Figs. 5 and 6).

\section{Discussion}

The combination of chemotherapy and radiotherapy of advanced HNSCC was developed to improve the often poor prognosis in these malignancies. Concomitant chemoradiotherapy with cytotoxic chemotherapeutics has improved overall and five-year survival rates of advanced HNSCC patients and also improved locoregional control rate. But new strategies and targeted therapy have been explored in the attempt to enhance survival rates in advanced HNSCC and especially unresectable HNSCC. Various experimental approaches have been investigated, as for example CD44v6 as a potential new target in HNSCC (7). Countless epigenetic and genetic events, including the aberrant expression and function of regulators of cell cycle, growth and signaling, motility, angiogenesis, and apoptosis are involved in pathogenesis of HNSCC and thus might be plausible targets for

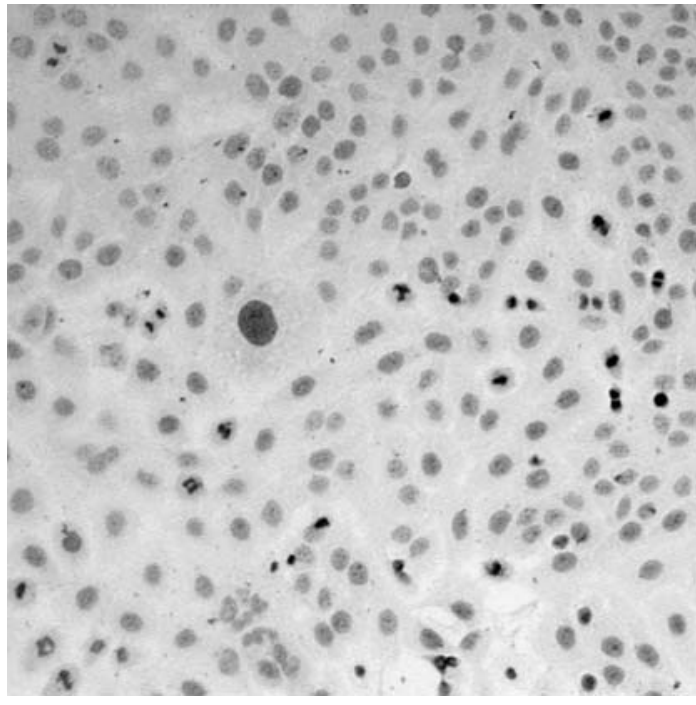

Figure 5. Positive immunohistochemical reactivity against c-kit after incubation for 5 days in the control group.

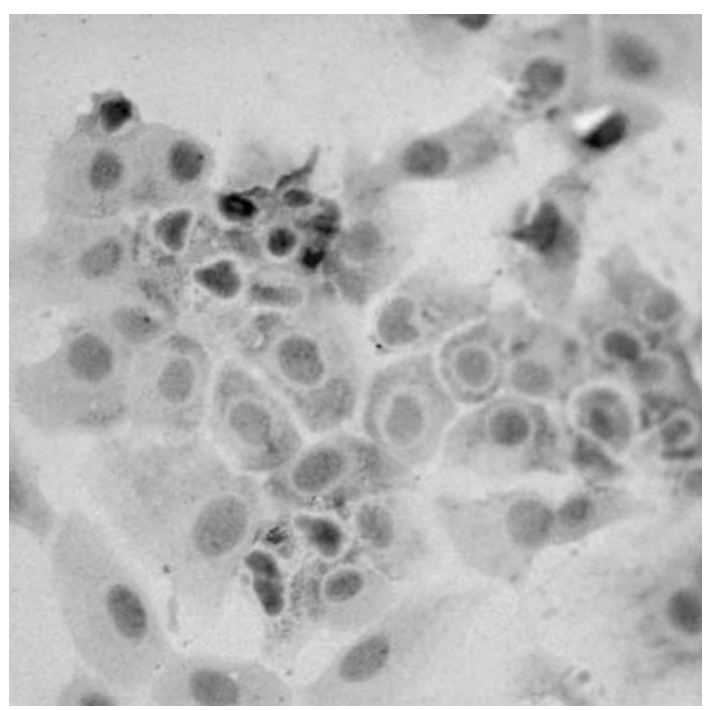

Figure 6. Positive immunhistochemical reactivity against c-kit after a 5-day incubation with $18 \mu \mathrm{mol}$ imatinib.

therapy. Thus, recently intracellular signal transduction has come to special interest also in squamous cell carcinoma. We set special interest in PTKs, as an essential element of signal transduction pathways. Defects of PTKs seem to be responsible for malignant transformations (8). In 2003, the first report of an EGFR-PTK inhibitor in HNSCC was described (9). Five years ago the first study analyzing the expression of c-kit in HNSCC was reported. Ongkeko et al described a significantly higher expression of c-kit in HNSCC compared to benign samples (17). Imatinib was originally designed to inhibit a certain tyrosine kinase in CML (10). But imatinib does also have an inhibitory impact on the PTK receptor c-kit and on its PTK activity (14). Imatinib can be administered orally to the patients and comparatively limited toxic side effects have been reported (15). In consequence, we set up the above-mentioned study to analyze its potency in HNSCC cell lines. 
The analysis of the c-kit expression could not demonstrate a significant difference between the incubated cultures and the control cultures. Nevertheless, the concentrations of imatinib used in our experiments were within the range that is achieved in a clinical trial. Similarly, the concentrations of carboplatin used in this study are clinically relevant. The presence of c-kit expression in UMSCC cell cultures has been demonstrated earlier (21). We supposed an antiproliferative effect of imatinib in HNSCC cell culture. In a similar study with an A549 NSCLC cell line, the incubation with imatinib and cisplatin resulted in increased antiproliferative effects (22). Thus, the c-kit status of the cell line might not be essential for synergistic effects of carboplatin. In consequence, some kind of interaction between imatinib and undefined kinases pertinent to carboplatin sensitivity might be possible. Furthermore, it is important to recognize that imatinib does not alter PTK protein expression but interacts in the PTK phosphorylation and activation (23). Imatinib connects reversibly to the ATP binding site of their target kinases and thereby inhibits their catalytic activity. Also in HNSCC, PTKs seem to be essential elements of tumor biology. Earlier studies of the cell cycle after imatinib and cisplatin treatment revealed a $\mathrm{G}_{1}$ accumulation (21). Imatinib seems to have a slight protective effect on the tumor cell populations by an enhanced $S$ and $G_{2}$ phase cell cycle arrest. This might protect the cells from a decent cytotoxic DNA damage by platin-containing drugs. Nevertheless, we did observe a reduced amount of colonies after treatment with imatinib and carboplatin compared to carboplatin alone. Furthermore, we found a reduced amount of total protein content after the combination of these two drugs. Thus, the protective effects of imatinib seem to be of minor importance. Another reason might be the down-regulation of the proapoptotic gene p63 by imatinib (24). This tumor suppressor demonstrated a remarkable alteration of the apoptotic impact on cells by cisplatin (24). Besides p73, p63 is essential for the full apoptotic activity of the p53 family of tumor suppressors (25).

The role of MMP's in tumor progress, invasion and metastasis has already been extensively studied $(26,27)$. Hereby MMPs are responsible for the alteration of basement membrane collagens (28). Thus imatinib, a synthetic serine protease inhibitor, has antitumor activities toward adenocarcinoma, e.g., colon cancer. However, its antitumor effects on other types of cancer have been less extensively studied. We investigated the biological activities of imatinib on cell proliferation, cell-invasive potential and gelatinase production in HNSCC. In our experiment we illustrated a remarkable expression of MMP-14 in immunhistochemistry in all three cell lines. The expression of MMP-14 after incubation with elevated concentrations of imatinib and carboplatin was slight to moderate. The ELISA also depicted significant reduced levels of MMP-2 compared to the controls after treatment with $30 \mu \mathrm{mol}$ imatinib and $30 \mu \mathrm{mol}$ imatinib + $7.5 \mu$ mol carboplatin. The inhibitory effect of imatinib on MMP-expression increased with increasing concentrations of carboplatin. The maximum concentration of $7.5 \mu \mathrm{mol}$ carboplatin showed a significant inhibition if administered together with rising concentrations of imatinib. Again this observation may be linked to the cytostatic effect of imatinib and the fact that carboplatin excerts its function in dividing cells, especially the $\mathrm{S}$ phase of the cell cycle. This has also been reported in other cytotoxic drugs, as for example 5-FU (29). The observed synergy between imatinib and carboplatin should be further evaluated. Paracrine interactions between proliferating HNSCC cancer colonies and stromal fibroblasts play a key role in the evaluation of potential synergistic effects. Gelatinase and various other factors being expressed by surrounding fibroblasts have a strong influence on the growth of cancer cells. Recent reports revealed that even the conditioned media from stromal fibroblasts cultured in the presence of imatinib suppressed growth in colon cancer cells (30). Imatinib might affect the secreted factors by fibroblasts around the cancer cells and thus might alter the growth of the tumor in the future. Furthermore, fibroblasts express stem cell factor (SCF), which is the natural ligand of c-kit and influences in a paracrine loop the invasive potential, growth and c-kit expression in certain fetal and cancer cells (31). Further reports, describing stromal fibroblasts as the source for MMP production in HNSCC, have been published (32). These data suggest that carcinoma cells might be able to induce MMP production in stromal fibroblasts. This overproduction of MMPs might assist cancer cells to metastasize and invade. MMP-2 expression was suppressed in the presence of imatinib in our cell cultures. MMP-2 seems to play a key role in degradation of basement membranes, which facilitates invasion and metastasis of tumor cells. The overexpression of MMP-2 is associated with local invasion by the tumor, lymph node metastasis and a poor survival rate (33). Fibroblasts secrete several growth factors, such as SCF, HGF, IGF and TGF-ß $(31,34)$. A proteolytic cleavage by MMPs might activate these growth factors, which leads to HNSCC cell growth. TGF-B and IGF are factors known to increase the membrane MT1-MMP expression in vascular smooth muscle (35). HGF might enhance the invasiveness of HNSCC by the induction of Ets-related E1AF transcription factor genes, whose products again activate MMP genes (36). Furthermore, HGF may foster the tumor invasion process by inducing a loss of ß-catenin/ cadherin-mediated cell-cell adhesion (37). Recent studies revealed an alteration of these cell-cell adhesion proteins in HNSCC by sulindac sulfone (38). Thus, a model summarizing the interactions between HNSCC cells and stromal fibroblasts may contain the secretion of growth factors by fibroblasts that foster the expression of MMPs.

In conclusion, we have shown that HNSCC cell lines express c-kit and MMP-2. We demonstrated that imatinib administered in combination with carboplatin can be very effective in inhibiting HNSCC cell proliferation. Furthermore, MMP-2 expression was suppressed in the presence of imatinib in the observed cell lines. Therefore, imatinib may exert in part its inhibitory effect on tumor cell growth via the blockage of the signal transduction of PTK receptors. Because of the low toxicity of imatinib in humans, further studies should be considered.

\section{Acknowledgements}

The authors thank Petra Prohaska for excellent technical support and Dr C. Weiss for her great assistance in statistical 
analysis. We thank Dr Thomas E. Carey, University of Michigan, USA for providing the UM-SCC cell lines and Novartis Pharma, Basel, Switzerland for providing imatinib.

\section{References}

1. Edwards BK, Howe HL, Ries LA, et al: Annual report to the nation on the status of cancer, 1973-1999, featuring implications of age and aging on U.S. cancer burden. Cancer 94: 2766-2792, 2002 .

2. Vokes E, Weichselbaum RR, Lippman SM and Hong WK: Head and neck cancer. N Engl J Med 328: 184-194, 1993.

3. Dimery IW and Hong WK: Overview of combined modality therapies for head and neck cancer. J Natl Cancer Inst 85: 95-111, 1993.

4. Gallo O, Chiarelli I, Boddi V, Bocciolini C, Bruschini L and Porfirio B: Cumulative prognostic value of p53 mutations and bcl-2 protein expression in head-and-neck cancer treated by radiotherapy. Int J Cancer 84: 573-579, 1999.

5. Grandis JR, Chakraborty A, Zeng Q, Melhem MF and Tweardy DJ: Downmodulation of TGF-alpha protein expression with antisense oligonucleotides inhibits proliferation of head and neck squamous carcinoma but not normal mucosal epithelial cells. J Cell Biochem 69: 55-62, 1998

6. Pignataro L, Pruneri G, Carboni N, Capaccio P, Cesana BM, Neri A and Buffa R: Clinical relevance of cyclin D1 protein overexpression in laryngeal squamous cell carcinoma. J Clin Oncol 16: 3069-3077, 1998

7. Sauter A, Kloft C, Gronau S, et al: Pharmacokinetics, immunogenicity and safety of bivatuzumab mertansine, a novel CD44v6-targeting immunoconjugate, in patients with squamous cell carcinoma of the head and neck. Int J Oncol 30: 927-935, 2007.

8. Blume-Jensen P and Hunter T: Oncogenic kinase signaling. Nature 411: 355-365, 2001

9. Ford A and Grandis JR: Targeting EGFR in HNSCC. Head Neck 25: 67-73, 2003

10. Druker BJ and Lydon NB: Lessons learned from the development of an Abl tyrosine kinase inhibitor for chronic myelogenous leukemia. J Clin Invest 105: 3-7, 2000.

11. Buchdunger E, Zimmerman J, Mett H, Meyer T, Muller M, Druker B and Lydon NB: Inhibition of the abl protein-tyrosine kinase in vitro and in vivo by a 2-phenylaminopyrimidine derivative. Cancer Res 56: 100-104, 1996.

12. Druker BJ, Tamura S, Buchdunger E, Ohno S, Segal GM, Fanning S, Zimmermann J and Lydon NB: Effects of a selective inhibitor of the ABL tyrosine kinase on the growth of bcr-abl positive cells. Nat Med 2: 561-566, 1996.

13. Bran B, Bran G, Hörmann K and Riedel F: The platelet-derived growth factor receptor as a target for vascular endothelial growth factor-mediated anti-angiogenetic therapy in head and neck cancer. Int J Oncol 34: 255-261, 2009.

14. Heinrich MC, Griffith DJ, Druker BJ, Wait CL, Ott KA and Zigler AJ: Inhibition of c-kit receptor tyrosine kinase activity by STI 571, a selective tyrosine kinase inhibitor. Blood 96 : 925-932, 2000

15. Hirota S, Isozaki K, Moriyama Y, et al: Gain-of-function mutations of c-kit in human gastrointestinal stromal tumors. Science 279: 577-580, 1998.

16. Hines S, Organ C, Kornstein M and Krystal GW: Co-expression of the c-kit and stem cell factor genes in breast carcinomas. Cell Growth Differ 6: 769-779, 1995.

17. Ongkeko WM, Altuna X, Weisman RA and Wang-Rodriguez J: Expression of protein tyrosine kinases in head and neck squamous cell carcinomas. Am J Clin Pathol 124: 71-76, 2005.

18. Bruce IA, Slevin NJ, Homer JJ, McGrown AT and Ward TH: Synergistic effects of imatinib in combination with chemotherapeutic drugs in head and neck cancer. Anticancer Drugs 16: 719-726, 2005.

19. O-Charoenrat P, Rhys-Evans PH and Eccles SA: Expression of matrix metalloproteinases and their inhibitors correlates with invasion and metastasis in squamous cell carcinoma of the head and neck. Arch Otolaryngol Head Neck Surg 127: 813-820, 2001.
20. Okada A, Belloq JP, Rouyer N, Chenard MP, Rio MC, Chambon P and Basset P: Membrane-type matrix metalloproteinase (MT-MMP) gene is expressed in stromal cells of human colon, breast, and head and neck carcinomas. Proc Natl Acad Sci USA 92: 2730-2734, 1995.

21. Wang-Rodriguez J, Lopez JP, Altuna X, Chu TS, Weisman RA and Ongkeko WM: STI-571 (Gleevec) potentiates the effect of cisplatin in inhibiting the proliferation of head and neck squamous cell carcinoma in vitro. Laryngoscope 116: 1409$1416,2006$.

22. Zhang P, Gao WY, Turner S and Ducatman B: Gleevec (STI 571) inhibits lung cancer cell growth (A549) and potentiates the cisplatin effect in vitro. Mol Cancer 2: 1-9, 2003

23. Bishayee S, Ross AH, Womer R and Scher CD: Purified human platelet-derived growth receptor has ligand-stimulated tyrosine kinase activity. Proc Natl Acad Sci USA 83: 67566760,1986

24. Ongkeko WM, An Y, Chu TS, Aguilera J, Dang CL and Wang-Rodriguez J: Gleevec suppresses p63 expression in head and neck squamous cell carcinoma despite p63 activation by DNA damaging agents. Laryngoscope 116: 1390-1396, 2006.

25. Flores ER, Tsai KY, Crowley D, Sengupta S, Yang A, McKeon F and Jacks T: p63 and p73 are required for p53-dependent apoptosis in response to DNA damage. Nature 416: 560-564, 2002.

26. Moscatelli D and Riflin DB: Membrane and matrix localization of proteinases: a common theme in tumor cell invasion and angiogenesis. Biochem Biophys Acta 948: 67-85, 1998.

27. Gorogh T, Beier UH, Baeumken J, Meyer JE, Hoffmann M, Gottschlich S and Maune S: Metalloproteinases and their inhibitors: influence on tumor invasiveness and metastasis formation in head and neck squamous cell carcinomas. Head Neck 28: 31-39, 2006

28. Liotta L and Stetler-Stevenson WG: Tumor invasion and metastasis: an imbalance of positive and negative regulation. Cancer Res 51: 5054-5059, 1990.

29. Pinedo HM and Peters GJ: Fluorouracil: biochemistry and pharmacology. J Clin Oncol 10: 1653-1664, 1988.

30. Stahtea XN, Roussidis AE, Kanakis I, et al: Imatinib inhibits colorectal cancer cell growth and suppresses stromal-induced growth stimulation, MT1-MMP expression and pro-MMP2 activation. Int J Cancer 121: 2808-2814, 2007.

31. Shimizu M, Minakuchi K, Tsuda A, Hiroi T, Tanaka N, Koga J and Kiyono H: Role of stem cell factor and c-kit signaling in regulation of fetal intestinal epithelial cell adhesion to fibronectin. Exp Cell Res 266: 311-322, 2001.

32. Rosenthal E, McCrory A, Talbert M, Carroll W, Magnuson JS and Peters GE: Expression of proteolytic enzymes in head and neck cancer-associated fibroblasts. Arch Otolaryngol Head Neck Surg 130: 943-947, 2004.

33. Seiki M: Membrane-type 1 matrix metalloproteinase: a key enzyme for tumor invasion. Cancer Lett 194: 1-11, 2003

34. Mook ORF, Frederiks WM and Noorden CJF: The role of gelatinases in colorectal cancer progression and metastasis. Biochim Biophys Acta 1705: 69-89, 2004.

35. Risinger GM, Hunt TS, Updike DL, Bullen EC and Howard EW: Matrix metalloproteinase-2 expression by vascular smooth muscle cells is mediated by both stimulatory and inhibitory signals in response to growth factors. J Biol Chem 281: 25915-21925, 2006.

36. Hanzawa M, Shindoh M, Higashino F, et al: Hepatocyte growth factor upregulates E1 AF that induces oral squamous cell carcinoma cell invasion by activating matrix metalloproteinases genes. Carcinogenesis 21: 1079-1085, 2000.

37. Hiscox S and Jiang WG: Hepatocyte growth factor/scatter factor disrupts epithelial tumor cell-cell adhesion: involvement of beta-catenin. Anticancer Res 19: 509-517, 1999.

38. Sauter A, Soulsby H, Hörmann K and Naim R: Sulindac sulfone induces a decrease of beta-catenin in HNSCC. Anticancer Res 30: 339-343, 2010. 